\title{
DYNAMIC STABILIZATION - A STRATEGY FOR THE DEVELOPMENT OF SMALL AND MEDIUM FAMILY ENTERPRISES
}

\begin{abstract}
Modern times confronts enterprises with many challenges that are expressed through innovation, entrepreneurship, creating new business models, creating a value chain or using innovative strategic solutions. All these features significantly affect the maintenance of the so-called dynamic stabilization. This is particularly important in relation to small and medium-sized family businesses. Especially that the activities of this group of enterprises should be considered in the context of the succession of the enterprise by the younger generations. Factors (both financial and market) that make up the long-term stability play a significant role in the enterprise growth process and translate into an active strategy of family businesses. The aim of the article is to show whether the actions taken in the life cycle of a small and medium enterprise are an expression of dynamic stabilization in the context of survival and development of a family business. Literature research and the results of own research may indicate the importance of an active (dynamic) strategy for the operation of family businesses. Effectiveness and creativity, commitment are also important characteristics of the entrepreneur, which will affect the so-called dynamic stabilization of the company. As it results from the analysis, knowledge, human capital and what is associated with the implementation of innovative ideas and solutions in the organizational, technological and product sphere are also undeniably important. Small and medium-sized businesses are attributed flexibility, creativity and dynamism, and they become the main driving forces for the development of small family businesses in the spirit of dynamic stabilization.
\end{abstract}

Keywords: dynamic stabilization, family businesses, family business strategies.

\section{INTRODUCTION}

It seems, on the surface, that the term "dynamic stabilization" as a simple combination of two words: dynamics and stabilization - is illogical. However, considering this concept in a broader context, especially in relation to business management processes - we are inspired by a number of concepts, prerequisites for their application, connections with various areas of the organization's activities. It is worth quoting only some of them here: innovation,

\footnotetext{
${ }^{1}$ Adriana Kaszuba-Perz, PhD, Rzeszow University of Technology, Faculty of Management, Department of Finance, Banking and Accountancy, Al. Powstańców Warszawy 12, 35-959 Rzeszów; e-mail: aperz@prz.edu.pl. ORCID: 0000-0001-9660-5140.

Dr Adriana Kaszuba-Perz, Politechnika Rzeszowska, Wydział Zarządzania, Zakład Finansów, Bankowości i Rachunkowości, Al. Powstańców Warszawy 12, 35-959 Rzeszów; e-mail: aperz@prz. edu.pl. ORCID: 0000-0001-9660-5140.
} 
entrepreneurship, creating the value chain, creating new business models, strategic management. Each of these elements will undoubtedly have a major impact on maintaining the company in dynamic stabilization. This is particularly important in relation to small and medium-sized family enterprises, which are usually described as creative, flexible, innovative and characterized by high entrepreneurship. The process of development of such an enterprise in the context of succession for subsequent generations must have features of dynamic stability. A trend in the literature related to the activity of the SMEs sector dealing with the specificity of SMEs ${ }^{2}$ may indicate the need to constantly conduct and expand research in the field of various activities undertaken by entities representing this group.

The aim of the paper is to show whether the undertaken activities in the life cycle of a small and medium-sized enterprise are a way to dynamically stabilize in the context of survival and development of a family business.

\section{STRATEGIES AND WAYS OF OPERATION OF SMALL AND MEDIUM-SIZED FAMILY ENTERPRISES - SPECIFIC FEATURES}

There are many definitions of family businesses in the literature, so it is worthwhile to distinguish the criteria common to their characteristics, among which they are first mentioned, the scope of ownership or legal control over its activity ${ }^{3}$. Also among Polish researchers there is a view that a family company is one in which at least two family members participate, while participation concerns both property and work ${ }^{4}$. Certainly, an important feature of family businesses is its orientation towards the future, which is a contribution to the way of operational management, which is widely assessed as much more efficient and economical. In addition, the high motivation and commitment of family members, perseverance, are also becoming important factors influencing the way of realizing the short and long-term goals of such an enterprise. An interesting review of the current research on the functioning of small and medium-sized family enterprises was made by A. Marjański ${ }^{5}$. This analysis shows that the research so far focused on the specificity of managing family businesses, in various areas (strategy, business mission, human resources, attitudes of the owner, etc.), they were usually conducted on small trials, however, confirm the complexity of the functioning of family businesses.

There are many different classification of business strategies, including those belonging to the group of family enterprises. The development of sciences in the field of strategic

${ }^{2}$ See amog others: O. Torrès, P.A. Julien, Specificity and Denaturing of Small Business, "International Small Business Journal", Vol. 23, No. 4/2005.

${ }^{3}$ R. Donckels, E. Fröhl, Are family businesses really different? European Experiences from Stratos., Family Business Review, Vol. 42, No. 4/1991 and Q. Fleming, Tajniki przetrwania firmy rodzinnej. Publ. One Press Small Business, 2000, pp. 105-107.

${ }^{4}$ J. Jeżak, W. Popczyk, A. Winnicka-Popczyk, Przedsiębiorstwa rodzinne. Funkcjonowanie i rozwój, Difin, Warszawa, 2004, pp. 9 and M. Stradomski, Finansowanie obce firm rodzinnych na rynku niedoskonatym, PWE, Warszaw, 2010, p. 41.

5 A. Marjański, Badania małych i średnich przedsiębiorstw rodzinnych w Polsce [w:] M. Matejun (ed.), Wyzwania i perspektywy zarządzania w matych i średnich przedsiębiorstwach, Wydawnictwo C.H. Beck, Warszawa, 2010, pp. 30-41. 
management led to the emergence of many approaches - schools, and their interesting typology presented, among others K. Obłój ${ }^{6}$, distinguishing: planning, evolutionary and positional school, as well as the school of resources and skills.

In the context of strategies used by small and medium-sized enterprises, the evolutionary school as well as resources and skills deserve attention. Because their features seem to coincide with the characteristic mode of operation of entrepreneurs from the SME sector, who are focused on continuous (dynamic) search for opportunities and the use of potential, knowledge, skills - as the main driving forces for staying on the market and further development. In turn, J. Penc ${ }^{7}$ distinguishes three basic groups of strategy for SMEs: defensive, offensive and pioneer. In a defensive strategy, the company focuses on reducing failures and surviving in the market. Therefore, entrepreneurs who undertake such a strategy are reluctant to approach all kinds of changes. The opposite is the offensive approach in which entrepreneurs show activity, creativity and willingness to take risks in the spirit of continuous progress. It is this strategy that creates a climate for innovation and continuous improvement and growth. Knowledge and human capital are of great importance in this strategy. In turn, pioneer strategies are based on innovative ideas in the field of products, services, technologies, distribution methods, etc. It seems that these strategies are characteristic of many small and medium-sized family businesses. The specificity of small and medium-sized enterprises translates into a way of managing them, including strategic management, as described in, among others M. Bednarczyk ${ }^{8}$. The author has made the typology and characteristics of the basic features of strategic management in small and medium-sized enterprises.

Interesting research on the strategies used by Polish small and medium-sized enterprises was also carried out by M. Oliński ${ }^{9}$. The author has attempted to associate strategic goals with two elements of the business model: creating value for the client and capturing values. His research shows that among the market objectives a large part of the surveyed companies lists: maintaining market shares, or their growth, customer satisfaction and loyalty, but also goals that pertain to product or process innovation. Among the financial goals, Oliński's research shows that entrepreneurs mostly focus on, among others, maintaining sales profitability, increasing sales revenues or maximizing profit. This is also confirmed by $\mathrm{K}$. Krukowski who has prioritized the strategic goals of small and medium-sized enterprises ${ }^{10}$.

The large diversity of family business models, also due to the emergence of new information and IT technologies in today's economy, leads to the belief that the previously known strategies of such companies will undoubtedly change. An interesting review of the definition of strategic management and strategy in the context of creating a business model

${ }^{6}$ K. Obłój, Strategia organizacji: budowanie trwałej przewagi konkurencyjne, PWE, Warszawa, 1996, pp. 15.

7 J. Penc, Strategie zarzadzania. Perspektywiczne myślenie, systemowe działanie, Warszawa 1995, p. 196.

${ }^{8}$ M. Bednarczyk, Otoczenie i przedsiębiorczość w zarządzaniu strategicznym organizacja gospodarcza, Zeszyty Naukowe. Monografie nr 128, Wydawnictwo Akademii Ekonomicznej w Krakowie, Kraków 1996, p. 83.

9 M. Oliński, Model biznesu w kontekście celów strategicznych przedsiębiorstwa, Studia Ekonomiczne. Zeszyty Naukowe Uniwersytetu Ekonomicznego w Katowicach nr 267/2016.

${ }^{10} \mathrm{~K}$. Krukowski, Cele strategiczne innowacyjnych matych i średnich przedsiębiorstw, Studia Ekonomiczne. Zeszyty Naukowe Uniwersytetu Ekonomicznego w Katowicach, nr 267/2016. 
was made in his work by M. Wierzbiński ${ }^{11}$. The method of gaining partners, clients, implementing innovative services/products, the possibility of remote implementation of research projects or other projects (through the use of modern messengers, for example) - these are factors that currently will have a major impact on the new way of operating micro, small and medium family enterprises.

\section{DYNAMIC STABILIZATION AS A WAY OF FUNCTIONING OF MODERN ENTERPRISES}

The necessity of constant implementation of changes that guarantee the existence of a company in a turbulent and highly competitive environment seems obvious today. However, it is not always a change - in a revolutionary sense - it must be the best solution for an enterprise. Frequently, constant care for dynamics of processes, activities that make up the functioning of an enterprise is more beneficial - as E. Abrahamson writes ${ }^{12}$. In turn, A.L. Platonoff in the definition of dynamic management draws attention to the complexity of this process, while emphasizing the importance of knowledge in this process and focus on continuous improvement of the organization in adapting to the needs of stakeholders ${ }^{13}$. In his work, A. Kwiecien ${ }^{14}$ emphasizes that through "the process of changes based on reliable and interdisciplinary knowledge and the transformation of attitude in people, and then its synchronization with the transformation of the organization, focused on development it is possible to achieve success and the right transformation of the enterprise". The concept of dynamic stabilization is fundamentally contradictory, combining two approaches in opposition: the first of them is exploration, innovation, propensity to take risks, seeking opportunities and their use, while the second one is maintaining the existing position through the use (exploitation) of resources. This concept in its studies is characterized by A. Zakrzewska-Bielawska ${ }^{15}$.

The complexity and multidimensionality of economic processes generates a huge demand for information. External and internal factors determining the functioning of business entities necessitate the use of innovative tools supporting the acquisition and processing of this information, this also applies to small and medium-sized family enterprises. Considering the specifics of these enterprises, both the size of the entity and the role of the entrepreneur - the owner in shaping the future, building its strategy, model and management style will be important factors causing the information needs. The system of specific features and

${ }^{11}$ M. Wierzbicki, Rachunkowość zarządcza w odnowie modelu biznesowego przedsiębiorstwa, Wrocław 2017, pp. 46-47.

12 E. Abrahamson, Bezbolesne zarządzanie zmiana, Harvard Business Review Polska, No. 5/2003.

13 A.L. Platonoff, Zarządzanie dynamiczne. Nowe podejście do zarządzania przedsiębiorstwem, Warszawa 2009, p. 40.

${ }^{14}$ A. Kwiecień, Zarzadzanie dynamiczne procesami biznesowymi - wyzwanie dla przedsiębiorstw XXI wieku, Studia Ekonomiczne. Zeszyty Naukowe Uniwersytetu Ekonomicznego w Katowicach, No. 322/2017.

15 A. Zakrzewska-Bielawska, Paradoks eksploracji i eksploatacji - Ambidexterity w zarzadzaniu strategicznym, Prace Naukowe Uniwersytetu Ekonomicznego we Wrocławiu, No. 420/ 2016 and A. Zakrzewska-Bielawska, Ambidexterity jako zdolność dynamiczna w odpowiedzi na niepewność otoczenia, Studia Oeconomica Posnaniensia, 2017, Vol. 5, No. 9, p. 174-190. 
factors shaping the special character of family enterprises can be treated as a kind of organizational entrepreneurship described, among others by M. Bratnicki ${ }^{16}$. Trying to link this concept with the idea of constant improvement of processes, introducing changes for building values - one may create a special business model aimed at a long-term perspective characteristic of family businesses. In turn, Wierzbicki ${ }^{17}$ emphasizes that the business model can be treated as an indispensable element of the company strategy and the way to implement it. Schumpeter speaks of "creative destruction" as a process of innovative solutions, having the character of a breakthrough in the enterprise and leading to its growth ${ }^{18}$. It seems, therefore, that the role of innovation in the process of building a business model in the spirit of dynamic stabilization is extremely important.

Innovation is variously defined. The most frequently appearing context of its definition is, of course, the technological context. However, from the point of view of the subject matter, it is worth quoting the definition used by Maital and Seshadri, emphasizing its main feature - creativity in each of the areas of the enterprise value chain ${ }^{19}$. In this context, the innovation may also apply to the ways of managing the enterprise in general and in each of its processes. For this reason, we can look at innovation from the point of view of implementing and implementing innovative solutions in the field of controlling and economic calculus. At the same time, many researchers emphasize the difficulties of research into the innovativeness of enterprises - referring to the areas of organization and internal processes of the entity ${ }^{20}$. Creativity, innovation, breakthroughs caused by "creative destruction" are undoubtedly manifestations of entrepreneurship - understood both as an attitude and as a kind of activity. Zbierowski emphasizes that the growth of the company is conditioned by entrepreneurship, and this in turn is linked to innovation ${ }^{21}$. The author also draws attention to the fact relating to the effectiveness of such an enterprise, namely that organizations that neglect development investments, although they can cope in the current operation, but in the long run their activities are at risk.

An interesting analysis and research on the choice between the strategy of expansion and stabilization in contemporary enterprises was carried out by A. Kaleta ${ }^{22}$. According to the author, in a turbulent and extremely demanding environment - in which companies operate today - only dynamic development and the use of expansive strategies can guarantee success.

Entrepreneurship referred to in the above considerations, the tendency to take risky decisions - which in themselves become a change and introduction of dynamism into action, are characteristics of small and medium-sized family enterprises. Therefore, it should be assumed that such a style of action, known as dynamic stabilization, is assigned to the character of family businesses.

${ }^{16}$ M. Bratnicki, Sprawdzanie teorii przedsiębiorczości, in: „Przedsiębiorstwo Przyszłości” 2011, No. 3(8), Kwartalnik Wyższej Szkoły Zarządzania i Prawa im. H. Chodkowskiej.

${ }^{17}$ M. Wierzbicki, Rachunkowość zarządcza w odnowie modelu biznesowego przedsiębiorstwa, Wrocław 2017, p. 51-52.

18 J.A. Schumpeter, Kapitalizm, socjalizm, demokracja, Warszawa 2009.

${ }^{19}$ S. Maital, D.V.R. Seshadri, Innovation Management: Strategies, Concepts and Tools for Growth and Profit, London 2007, p. 29.

${ }^{20}$ D. Audretsch, Entrepreneurship research., "Management Decision" 2012, No. 50(5).

${ }_{21}$ P. Zbierowski, Orientacja pozytywna organizacji wysokiej efektywności, Warszawa 2012, p. 23.

22 A. Kaleta, Strategia ekspansji czy stabilizacji?, Zarządzanie strategiczne w teorii i praktyce, Prace Naukowe Uniwersytetu Ekonomicznego we Wrocławiu, No. 366/2014. 


\section{BUILDING STABILITY OF A FAMILY BUSINESS AND DYNAMIC CHANGES IN ITS HISTORY - RESEARCH RESULTS}

The analysis presented below is a fragment of more extensive research currently being conducted. The research is carried out on a group of small and medium-sized family enterprises located in the Podkarpackie Voivodeship. In order to select the sample, the definitions of small ${ }^{23}$ and medium-sized enterprises and a family enterprise ${ }^{24}$ known in the literature were used. So far, 110 small and medium-sized enterprises have been surveyed, of which 53 have been identified as family enterprises.

Interesting research on the course of development processes in Polish small and medium-sized enterprises in the context of their resourceful dynamic capabilities was carried out by M. Matejun and A. Motyka ${ }^{25}$. The authors, based on the cited concepts of phase models of life and development of SMEs ${ }^{26}$ also presented their own proposition of a phased dynamics of the life cycle of companies from the SMEs sector, consisting of eight stages and referring to the specificity of this sector ${ }^{27}$. Appreciating the achievements of many scientists involved in researching the growth and life cycle of small and medium-sized enterprises, for the purpose of this study the popular concept of the Churchila and Levis growth process was used, considering it the most universal ${ }^{28}$. Thus, the development process of a small and medium-sized enterprise was divided into 5 stages, i.e.: the creation of a company, survival, success - through growth (maintaining a favorable market position), development (increase in the size of the enterprise, the scope of its operations) and the maturity phase. Against this background, they were asked in a survey, among others, for the entrepreneurs to indicate the most important events affecting the growth or transformation in the subsequent stages of a company's life. Due to the fact that the conducted research has a wider scope, only the fragment related to the subject taken in the article was used in this study.

Due to the specificity of family businesses, especially the smallest ones, it is worth emphasizing that entrepreneurs are not always able to link and unambiguously assess the effects of undertaken activities with the transition to the next phase of development. This seems understandable because often these activities are interrelated and taken together so choosing one of them - as a spectacular, having an impact on the company's future - may seem difficult. However, many of the respondents indicated many events, actions and ventures that contributed to the dynamic development of their enterprises. Table 1 presents the

${ }^{23}$ The Act of 2 July 2004 on the freedom of economic activity and OJ on November 10, 2016. Pos. 1829. Manufacturing. Marshal Of The Sejm Of The Republic Of Poland dated 12 October 2016 regarding the publication of a uniform text of the Act on the freedom of economic activity.

24 Ibidem.

${ }_{25}$ M. Matejun, A. Motyka, Zasobowe zdolności dynamiczne w zarzadzaniu rozwojem firm sektora MSP, Monografie Politechniki Łódzkiej, Łódź 2016.

${ }^{26}$ See: M. Scott, R. Bruce, Five Stages of Growthin Small Business, "Long Range Planning”, Vol. 20, No. 3/1987 and E. Masurel, K. Van Montfort, Life Cycle Characteristics of Small Professional Service Firms, "Journal of Small Business Management", Vol. 44, No. 3/2006.

${ }_{27}$ M. Matejun, A. Motyka, Zasobowe zdolności dynamiczne w zarzadzaniu rozwojem firm sektora MSP, Monografie Politechniki Łódzkiej, Łódź 2016, p. 34-35.

28 N.C. Churchil and V.L. Levis, The five stages of small business growth, "Harvard Business Review", May-June 1983. 
events most frequently mentioned by representatives of small and medium-sized family enterprises, which significantly affected the life of their company in the long-term or to build their stabilization.

From data obtained during research, it is easy to notice that each of the entrepreneurs strives to maintain the stability of their company to a greater or lesser extent. The events identified in the study and identified as those that were of significant importance in the history of the surveyed entities - confirm the entrepreneur's activity in continually analyzing the threats and opportunities appearing in the environment and in striving to keep the company at least in the current position or in the future.

Table 1. Significant events affecting the dynamics of the company's development in the opinion of entrepreneurs

\begin{tabular}{|l|c|}
\hline \multicolumn{1}{|c|}{$\begin{array}{c}\text { An event identified by the surveyed representatives of family } \\
\text { businesses }\end{array}$} & $\begin{array}{c}\text { Number of identical or } \\
\text { similar answers }\end{array}$ \\
\hline Investments in fixed assets & $18,9 \%$ \\
\hline Signing contracts with new partners/ contractors/clients & $18,9 \%$ \\
\hline Entering foreign markets & $9,4 \%$ \\
\hline Expanding the market/opening new branches & $3,7 \%$ \\
\hline Limiting/separating and liquidating unprofitable areas of activity & $5,6 \%$ \\
\hline Obtaining new permissions/certificates & $3,7 \%$ \\
\hline $\begin{array}{l}\text { Launching new products/services into the market (including inno- } \\
\text { vative ones) }\end{array}$ & $15,1 \%$ \\
\hline Implementation of specialist/cutting-edge technologies & $1,8 \%$ \\
\hline Achievement of financial stability & $5,6 \%$ \\
\hline Financial contribution through EU subsidies & $7,5 \%$ \\
\hline An increase of employment & $1,8 \%$ \\
\hline Introduction of a new pricing policy & $1,8 \%$ \\
\hline $\begin{array}{l}\text { An application of new/innovative marketing methods and tech- } \\
\text { niques }\end{array}$ & $1,8 \%$ \\
\hline
\end{tabular}

* the received responses do not add up to $100 \%$, as entrepreneurs could indicate more than one answer.

Source: own study based on the conducted research.

The largest number of entrepreneurs (18.9\%) exchanged investments and contracts with new partners - as key events in their development. On the other hand, there are implementations of new products/services - this also applies to innovative and innovative ideas related to business operations (over $15 \%$ of respondents). Over $9 \%$ of surveyed entrepreneurs declared entering foreign markets as a significant event for the growth of their enterprises. All of the answers mentioned required a lot of commitment from the owner - which was emphasized in the statements of entrepreneurs. This activity proves that without precise definition and naming by entrepreneurs of the applied strategy - they undertake attempts of offensive actions, but in the context of maintaining the company's stability. It is the stabilization in family businesses that is crucial - a thriving enterprise provides financial security to successive generations - successors.

Table 2 presents the data on the specification of the moment in the life cycle of the company which experienced the key events for their history. Both representatives of micro 
and small enterprises most often indicated Phase 3 - as the one in which significant events occurred that had an impact on the operations of the family business. In the case of mediumsized enterprises, the most, because more than $8 \%$ of respondents indicated phase 4 . It is worth noting here that a different view as to the moment when the most important events occur in the company's life cycle may result from different age of enterprises. Most of the surveyed companies assessed their age as Phase 3 and 4, few (especially medium ones) described themselves as mature enterprises. Only a few among the surveyed enterprises indicated the survival phase (these were microenterprises).

Table 2. The moment of occurrence of events significant for the life of the enterprise in the opinion of entrepreneurs

\begin{tabular}{|l|c|c|c|c|c|}
\cline { 2 - 6 } \multicolumn{1}{c|}{} & $\begin{array}{c}\text { Phase 1 } \\
\text { Establishment } \\
\text { of the company } \\
\text { - presence in } \\
\text { the market } \\
\text { - market recog- } \\
\text { nition }\end{array}$ & $\begin{array}{c}\text { Phase 2 } \\
\text { Survival } \\
\text {-customers } \\
\text { acquisition }\end{array}$ & $\begin{array}{c}\text { Maintaining } \\
\text { a favorable } \\
\text { market position/ } \\
\text { working out } \\
\text { a success }\end{array}$ & $\begin{array}{c}\text { Phase 4 } \\
\text { Increase in size, } \\
\text { scope of the } \\
\text { company's } \\
\text { activity, } \\
\text { - increase in } \\
\text { employment } \\
\text { - product and } \\
\text { technological } \\
\text { implementation, } \\
\text { etc. }\end{array}$ & $\begin{array}{c}\text { Phase 5 } \\
\text { Maturity } \\
\text { - care for the } \\
\text { quality of pro- } \\
\text { ducts and ser- } \\
\text { vices }\end{array}$ \\
\hline $\begin{array}{l}\text { Mikroenter- } \\
\text { prises }\end{array}$ & $12,3 \%$ & $10,5 \%$ & $19,3 \%$ & $5,3 \%$ & $5,3 \%$ \\
\hline $\begin{array}{l}\text { Small } \\
\text { enterprises }\end{array}$ & $5,3 \%$ & $1,8 \%$ & $7 \%$ & $5,3 \%$ & $3,5 \%$ \\
\hline $\begin{array}{l}\text { Medium- } \\
\text { sized } \\
\text { enterprises }\end{array}$ & $1,8 \%$ & $7 \%$ & $5,3 \%$ & $8,7 \%$ & $1,8 \%$ \\
\hline
\end{tabular}

* the received responses do not add up to $100 \%$, as entrepreneurs could indicate more than one answer. Source: own study based on research (The company's growth phases were based on literature studies, including: N.C. Churchil and V.L.Levis, The five stages of small business growth, Harvard Business Review, May-June 1983).

The presented research results can be a sign of the great care of entrepreneurs in the constant search for opportunities for development. Most of the respondents emphasize the huge role of the entrepreneur-owner in building the company's value and shaping its future. An additional factor affecting the creation of development and maintaining the company's stability in the future is the fact that the current owners strive for the financial security of the family now and in the future. Many of them associate the future of the enterprise with the next generation - successors. Thus, it seems that the dynamic strategy (in relation to the activities undertaken for development) of stabilization (for keeping the company in good condition in order to pass it on to future generations) seems to be an attractive and right approach in the management of long-term family businesses. Such an approach can also be treated as a specific model of running a family business, because in a management system aimed at constant care for high efficiency, profitability, and business development, ethical 
and moral values are of great importance. These are, as E. Wrońska-Bukalska writes, developed systems of values, defined as rules and rules concerning the functioning of family entities are their characteristic features ${ }^{29}$.

\section{CONCLUSIONS}

Literature studies carried out, as well as the results of research quoted above may indicate the importance of an active (dynamic) strategy for the functioning of family businesses, especially considering the perspective of transferring the enterprise to future generations. Of course, the adopted business model, but also the industry, the size and age of the enterprise, growth opportunities - are factors with a high degree of impact on the future of the business entity. This consists in the overall effectiveness of the company, both in the financial and market context. It is worth quoting the view of Zbierowski who notices in this respect the contradictions in managing the efficiency of enterprises, including small and medium-sized families ${ }^{30}$. Referring to the operational-short-term perspective, the author points to routine actions, the domination of material factors for the development of profitability - satisfying only the needs of the owners. In the long-term perspective, business management is characterized by the dominance of intangible factors, the search for new solutions, oriented to the needs of various groups of "stakeholders".

Indeed, in the case of microenterprises, an ad hoc focus on the financial result satisfying the owner-entrepreneur is generally perceived. Especially, if such an activity is carried out in the services sector and concerns only the local market. A slightly different approach will be characteristic of micro, small and medium enterprises in the production sector (even if they are specialized, niche products). The entrepreneurs of this group, already in the second phase of company life, i.e. survival, often start to undertake various activities aimed at developing the company in the long run. These activities increase with the age of the company, but also depend on the growth rate of the company. Undeniably in this respect knowledge, human capital and what is associated with the implementation of innovative ideas and solutions, both product, technological and organizational ones acquire significance.

\section{REFERENCES}

1. Abrahamson E., Bezbolesne zarzadzanie zmiana, Harvard Business Review Polska, No. 5, July 2003.

2. Audretsch D., Entrepreneurship research, "Management Decision" 2012, 50(5).

3. Bratnicki M., Sprawdzanie teorii przedsiębiorczości, Przedsiębiorstwo przyszłości, No. 3(8), July 2011, Kwartalnik Wyższej Szkoły Zarządzania i Prawa im. H. Chodkowskiej.

4. Bednarczyk M., Otoczenie i przedsiębiorczość w zarządzaniu strategicznym organizacja gospodarcza, Zeszyty Naukowe. Monografie No. 128, Wydawnictwo Akademii Ekonomicznej w Krakowie, Kraków 1996.

${ }^{29}$ E. Wrońska-Bukalska, Specyfika przedsiębiorstw sektora matych i średnich przedsiębiorstw [w:] E. Wrońska-Bukalska (ed.), System finansowy małego i średniego przedsiębiorstwa, Warszawa, 2015, p. 25-27.

${ }^{30}$ P. Zbierowski, Organizacje wysokiej efektywności [w:] T. Dudycz (ed.), Uwarunkowania i prawidtowości gospodarcze wywierające wpływ na efektywność funkcjonowania przedsiębiorstw, Wrocław 2008. 
5. Churchil N.C., Levis V.L., The five stages of small business growth, "Harvard Business Review", May-June 1983.

6. Donckels R., Fröhl E., Are family businesses really different? European Experiences from Stratos, "Family Business Review", Vol. 42, No. 4/1991.

7. Fleming Q., Tajniki przetrwania firmy rodzinnej. Publ. One Press Small Business, Warszawa 2000.

8. Jeżak J., Popczyk W., Winnicka-Popczyk A., Przedsiębiorstwa rodzinne. Funkcjonowanie i rozwój, Difin, Warszawa 2004.

9. Kaleta A., Strategia ekspansji czy stabilizacji?, Zarzadzanie strategiczne w teorii i praktyce, Prace Naukowe Uniwersytetu Ekonomicznego we Wrocławiu, No. 366/2014.

10. Krukowski K., Cele strategiczne innowacyjnych matych i średnich przedsiębiorstw, Studia Ekonomiczne. Zeszyty Naukowe Uniwersytetu Ekonomicznego w Katowicach, No. 267/2016.

11. Kwiecień A., Zarządzanie dynamiczne procesami biznesowymi - wyzwanie dla przedsiębiorstw XXI wieku, Studia Ekonomiczne. Zeszyty Naukowe Uniwersytetu Ekonomicznego w Katowicach, No. 322/2017.

12. Maital S., Seshadri D.V.R., Innovation Management: Strategies, Concepts and Tools for Growth and Profit, Response Books, London 2007.

13. Marjański A., Badania małych i średnich przedsiębiorstw rodzinnych w Polsce [w:] M. Matejun (ed.), Wyzwania i perspektywy zarządzania w matych i średnich przedsiębiorstwach, Wydawnictwo C.H. Beck, Warszawa 2010.

14. Masurel E., Van Montfort K., Life Cycle Characteristics of Small Professional Service Firms, "Journal of Small Business Management", Vol. 44, No. 3/2006.

15. Matejun M., Motyka A., Zasobowe zdolności dynamiczne w zarządzaniu rozwojem firm sektora MSP, Monografie Politechniki Łódzkiej, Łódź 2016.

16. Obłój K., Strategia organizacji: budowanie trwałej przewagi konkurencyjnej, PWE, Warszawa 1996.

17. Oliński M., Model biznesu w kontekście celów strategicznych przedsiębiorstwa, Studia Ekonomiczne. Zeszyty Naukowe Uniwersytetu Ekonomicznego w Katowicach, No. 267/2016.

18. Penc J., Strategie zarzadzania. Perspektywiczne myślenie, systemowe działanie, Placet, Warszawa 1995.

19. Platonoff A.L., Zarządzanie dynamiczne. Nowe podejście do zarządzania przedsiębiorstwem, Difin, Warszawa 2009.

20. Schumpeter J.A., Kapitalizm, socjalizm, demokracja, Wydawnictwo Naukowe PWN, Warszawa 2009.

21. Scott M., Bruce R., Five Stages of Growth in Small Business, "Long Range Planning", Vol. 20, No. 3/1987.

22. Stradomski M., Finansowanie obce firm rodzinnych na rynku niedoskonatym, PWE, Warszawa 2010.

23. Torrès O., Julien, P.A., Specificity and Denaturing of Small Business, "International Small Business Journal", Vol. 23, No. 4/2005.

24. Wierzbicki M., Rachunkowość zarządcza w odnowie modelu biznesowego przedsiębiorstwa, Wydawnictwo Uniwersytetu Ekonomicznego we Wrocławiu, Wrocław 2017.

25. Wrońska-Bukalska E., Specyfika przedsiębiorstw sektora matych i średnich przedsiębiorstw, [w:] E. Wrońska-Bukalska (ed.), System finansowy matego i średniego przedsiębiorstwa, Difin, Warszawa 2015. 
26. Zakrzewska-Bielawska A., Paradoks eksploracji i eksploatacji-Ambidexterity w zarzqdzaniu strategicznym, Prace Naukowe Uniwersytetu Ekonomicznego we Wrocławiu, No. 420/ 2016.

27. Zakrzewska-Bielawska A., Ambidexterity jako zdolność dynamiczna w odpowiedzi na niepewność otoczenia, Studia Oeconomica Posnaniensia, 2017, Vol. 5, No. 9.

28. Zbierowski P., Orientacja pozytywna organizacji wysokiej efektywności, Oficyna Wolters Kluwer Polska S.A., Warszawa 2012.

29. Zbierowski P., Organizacje wysokiej efektywności [w:] T. Dudycz (ed.), Uwarunkowania i prawidłowości gospodarcze wywierające wptyw na efektywność funkcjonowania przedsiębiorstw, Indygo Zahir Media, Wrocław 2008.

\section{DYNAMICZNA STABILIZACJA JAKO STRATEGIA ROZWOJU MAŁYCH I ŚREDNICH FIRM RODZINNYCH}

Współczesność stawia przed przedsiębiorstwami wiele wyzwań, które wyrażane są poprzez innowacyjność, przedsiębiorczość, kreowanie nowych modeli biznesowych, tworzenie łańcucha wartości czy stosowanie nowatorskich rozwiązań strategicznych. Wszystkie te cechy znacząco wpływają na utrzymanie tzw. dynamicznej stabilizacji. Szczególnego znaczenia nabiera to w odniesieniu do małych i średnich firm rodzinnych. Zwłaszcza iż działalność tej grupy przedsiębiorstw należy rozpatrywać w kontekście sukcesji przedsiębiorstwa przez młodsze pokolenia. Czynniki (zarówno te finansowe, jak i rynkowe) składające się na stabilność w długiej perspektywie, odgrywają znaczącą rolę w procesie wzrostu przedsiębiorstwa i przekładają się na aktywną strategię firm rodzinnych. Duże znaczenie w tym względzie mają wiedza i świadomość właściciela o potrzebie analizy uwarunkowań kształtujących przyszłość firmy oraz podejmowane przez niego aktywności. Celem artykułu jest wykazanie, czy podjęte działania w cyklu życia małego i średniego przedsiębiorstwa są wyrazem dynamicznej stabilizacji w kontekście przetrwania i rozwoju firmy rodzinnej. Przeprowadzone badania literaturowe oraz wyniki badań własnych, mogą świadczyć o znaczeniu aktywnej (dynamicznej) strategii funkcjonowania firm rodzinnych. Oczywiście przyjęty model biznesowy, ale także branża, wielkość i wiek przedsiębiorstwa, możliwości rozwoju - są czynnikami mającymi duży wpływ na przyszłość jednostki gospodarczej. Skuteczność działania i kreatywność, zaangażowanie to także istotne cechy przedsiębiorcy, które będą wpływały na dynamiczną stabilizację firmy. Jak wynika z przeprowadzonej analizy, niezaprzeczalnie ważna jest również wiedza, kapitał ludzki i to, co wiąże się z wdrażaniem innowacyjnych pomysłów i rozwiązań w sferze organizacyjnej, technologicznej jak i produktowej. Małym i średnim firmom przypisuje się elastyczność, kreatywność i dynamizm, i to one stają się głównymi siłami napędzającymi rozwój małych firm rodzinnych w duchu dynamicznej stabilizacji.

Słowa kluczowe: dynamiczna stabilizacja, firmy rodzinne, strategie firm rodzinnych.

DOI: $10.7862 / \mathrm{rz} .2018 . \mathrm{mmr} .44$

Tekst złożono do redakcji: lipiec 2018 r. Tekst przyjęto do druku: grudzień 2018 r. 
